\title{
ANALISIS PENGARUH CORPORATE SOCIAL RESPONSIBILITY, TAX AVOIDANCE TERHADAP NILAI PERUSAHAAN DENGAN KEPEMILIKAN ASING SEBAGAI VARIABEL MODERASI PADA PERUSAHAAN MANUFAKTUR DI BEI PERIODE 2016 - 2018
}

\author{
Nikki Kwok ${ }^{1)}$, Andi Gunawan Kwok ${ }^{2)}$ \\ ${ }^{1)}$ Akuntansi, Universitas Trisaksi \\ Email:nikkikwok@yahoo.com \\ ${ }^{2)}$ Akuntansi, Institut Bisnis dan Informatika Kwik Kian Gie
}

\begin{abstract}
The main goal of the company is to maximize prosperity for shareholders, this can be achieved by maximizing the value of the company. This research was conducted to determine the factors that influence the value of the company to be studied are Corporate Social Responsibility and Tax Avoidance. The moderating variable in this study is Foreign Ownership. The sample of this research is manufacturing companies whose shares are listed on the Indonesia Stock Exchange for the period of 2016-2018 using purposive sampling method. While the analytical method used is the classic assumption test and hypothesis testThe results of this study indicate that corporate social responsibility has no influence on firm value, and tax avoidance has an influence on firm value. Foreign ownership is not able to be a moderating variable that strengthens the relationship between corporate social responsibility and corporate value while foreign ownership is able to be a moderating variable that strengthens the relationship between tax avoidance and firm value.
\end{abstract}

Keywords: Firm value, Corporate Social Responsibility, Tax Avoidance and Foreign Ownership

\begin{abstract}
Abstrak: Tujuan utama perusahaan adalah untuk memaksimalkan kemakmuran bagi pemegang saham, hal ini dapat dicapai dengan memaksimalkan nilai perusahaan. Penelitian ini dilakukan untuk mengetahui faktor-faktor yang mempengaruhi nilai perusahaan yang akan diteliti adalah Corporate Social Responsibility dan Tax Avoidance. Variabel Moderating pada penelitian ini adalah Kepemilikan Asing.Sampel penelitian ini adalah perusahaan manufaktur yang sahamnya terdaftar di Bursa Efek Indonesia periode 2016-2018 dengan menggunakan metode purposive sampling. Sedangkan metode analisis yang digunakan adalah uji asumsi klasik dan uji hipotesis. Hasil penelitian ini menunjukkan bahwa corporate social responsibility tidak memiliki pengaruh terhadap nilai perusahaan, dan tax avoidance memiliki pengaruh terhadap nilai perusahaan. Kepemilikan asing tidak mampu menjadi variabel moderating yang memperkuat hubungan antara corporate social responsibility dengan nilai perusahaan sedangkan Kepemilikan asing mampu menjadi variabel moderating yang memperkuat hubungan antara tax avoidance dengan nilai perusahaan.
\end{abstract}

Kata Kunci: Nilai Perusahaan, Corporate Social Responsibility, Tax Avoidance dan Kepemilikan Asing. 


\section{Pendahuluan}

Perkembangan dunia usaha pada saat ini semakin pesat, banyak perusahaan bersaing ketat untuk memberikan kemakmuran yang sebesarbesarnya bagi para pemegang sahamnya dengan cara memaksimalkan nilai perusahaan. Usaha untuk meraih kinerja yang baik selalu diupayakan untuk dapat mencapai nilai yang baik bagi perusahaan. Hal ini dapat terwujud bila perusahaan dapat memaksimalisasi nilai pasar atas harga saham perusahaannya (Galatang et al. 2016). Persepsi investor terhadap suatu perusahaan terletak pada nilai perusahaan, dalam hal ini berkaitan dengan harga saham. Nilai perusahaan tercermin pada nilai pendapatan yang diinginkan dimasa yang akan datang dan menjadi indikator bagi pasar dalam menilai perusahaan secara keseluruhan (Manoppo dan Arie, 2016). Nilai perusahaan dapat juga tercermin dari harga saham yang stabil, harga saham yang dalam jangka panjang terus mengalami kenaikan, karena suatu perusahaan yang semakin tinggi harga sahamnya maka semakin tinggi pula nilai perusahaan tersebut (Languju et al. 2016).

Menurut Choi et al. (2012) kepemilikan asing memiliki kesempatan untuk mempengaruhi manajemen dan kebijakan perusahaan. Investor asing sebagai pemegang saham utama memiliki kemampuan untuk mengontrol dan memonitor keanggotaan dewan manajemen, menerapkan pengendalian manajemen, serta mengatur tata kelola perusahaan (corporate governance). Kepemilikan asing dalam suatu perusahaan akan membentuk manajemen yang lebih efisien dalam hal meningkatkan tata kelola perusahaan dengan tujuan untuk meningkatkan nilai perusahaan. Bila kepemilikan asing berhasil memiliki kemampuan untuk melakukan pengendalian dan monitor terhadap manjemen, maka kepemilikan asing memainkan peran penting dalam meningkatkan nilai perusahaan dengan meningkatkan reputasi perusahaan di pasar, sebaliknya bila tidak memiliki kemampuan maka mengakibatkan nilai perusahaan akan menurun seiring dengan merosotnya reputasi perusahaan di pasar.

Terdapat adanya beberapa faktor yang mempengaruhi nilai perusahaan, penjelasan mengenai Corporate Social Responsibility, Tax Avoidance telah disampaikan sebelumnya. Hal yang membedakan penelitian ini dengan penelitian-penelitian sebelumnya adalah terdapat kepemilikan asing sebagai variable Moderasi. Maka dari itu, peneliti beranggapan Kepemilikan asing mampu mempengaruhi hubungan antara corporate Social Responsibility, Tax Avoidance dengan nilai perusahaan. Perbedaan lain dengan penelitian sebelumnya adalah periode tahun yang digunakan yaitu tiga tahun pengamatan (2016-2018).

Rumusan masalah dalam penelitian adalah sebagai berikut :

1. Apakah terdapat pengaruh Corporate Social Responsibility terhadap Nilai Perusahaan?

2. Apakah terdapat pengaruh Tax Avoidance terhadap Nilai Perusahaan?

3. Apakah Kepemilikan Asing berpengaruh terhadap hubungan antara Laporan Corporate Social Responsibility dan Nilai Perusahaan $?$

4. Apakah Kepemilikan Asing berpengaruh terhadap hubungan antara Tax Avoidance dan Nilai Perusahaan?

Berdasarkan perumusan masalah penelitian yang telah disampaikan maka tujuan penelitian ini adalah sebagai berikut :

1. Untuk mengetahui, apakah Corporate Social Responsibility mempengaruhi Nilai Perusahaan. 
2. Untuk mengetahui, apakah Tax Avoidance mempengaruhi Nilai Perusahaan.

3. Untuk mengetahui, apakah Kepemilikan Asing mempengaruhi hubungan antara Corporate Social Responsibility dan Nilai Perusahaan.

4. Untuk mengetahui, apakah Kepemilikan Asing mempengaruhi hubungan antara Tax Avoidance dan Nilai Perusahaan.

Diharapkan dengan penelitian ini terdapat banyak pihak yang memperoleh manfaat diataranya adalah:

1. Bagi Akademisi, hasil penelitian ini diharapkan dapat memberikan nilai tambah berupa pengetahuan dan wawasan mengenai Corporate Social Responsibility, Tax Avoidance terhadap Nilai Perusahaan dengan Kepemilikan Asing sebagai variabel moderasi.

2. Bagi Perusahaan, penelitian ini diharapkan dapat memberikan informasi yang bermanfaat dan sebagai bahan pertimbangan dalam rangka meningkatkan nilai perusahaan.

3. Bagi para investors dan stakeholders, penelitian ini diharapkan dapat memberikan informasi yang berguna dan memadai dalam rangka pengambilan keputusan investasi, terutama dalam hal yang berkaitan dengan kinerja perusahaan dan nilai perusahaan

\section{Metode Penelitian}

Pendekatan yang digunakan dalam penelitian ini adalah pendekatan kuantiatif yang berbentuk kausalitas. Subjek dalam penelitian ini dilakukan pada perusahaan Manufaktur yang ada di Bursa Efek Indonesia (BEI) dengan cara mengakses halaman www.idx.co.id atau untuk mendapatkan infomrasi yang diungkapkan dalam laporan keuangan dan laporan taunan perusahaan manufaktur periode 2016-2018.
Dalam penelitian ini, yang menjadi objek penelitian adalah laporan keuangan auditan dan annual report perusahaan manufaktur yang terdaftar di bursa efek Indonesia per 31 desember . Objek penelitian ini untuk mengetahui seberapa besar pengaruh yang ditimbulkan dari CSR, tax avoidance, sebagai variabel independen terhadap nilai perusahaan sebagai variabel dependen dan menggunakan variabel moderasi Kepemilikan Asing.

Jenis penelitian yang digunakan penulis dalam penelitian ini adalah deskriptif kuantitatif. Deskriptif kuantitatif menjelaskan hubungan antara variable independen, variable dependen dan variabel moderasi.

Populasi yang digunakan dalam penelitian ini adalah perusahan perusahaan manufaktur yang terdaftar di bursa efek Indonesia periode 2016 2018.

Sampel yang di gunakan dalam penelitian ini ialah perusahaan perusahaan industry manufaktur yang terdaftar di Bursa Efek Indonesia. Salah satu alasan dalam pemilihan sampel tersebut ialah untuk kemudahan dalam pencarian data. Metode yang di gunakan adalah metode purposive sampling yaitu pemilihan sampel dengan pertimbangan tertentu sehingga perusahaan yang tidak sesuai dengan kriteria yang ditentukan peneliti akan dikeluarkan dari sampel. Adapun kriteria-kriteria yang ditetapkan dalam pengambilan sampel pada penelitian ini ditentukan sebagai berikut:

1. seluruh perusahaan sektor manufaktur yang listing di BEI tahun 2016-2018

2. Perusahaan manufaktur tidak menerbitkan laporan keuangan, annual report selama tahun 20162018

3. Perusahaan yang tidak memiliki kepemilikan asing

4. Perusahaan sektor manufaktur yang tidak memiliki data yang lengkap untuk mendukung penelitian 
5. Perusahaan yang mengalami kerugian

6. Data yang di outlier

\section{Pengelolaan data}

Pengolahan data dilakukan dengan cara menggunakan program. Microsoft Office Exel 2016, kemudian variabel-variabel yang telah dihitung tersebut diolah dengan menggunakan program Statistical Product and Service Solution (SPSS) versi 25 untuk menghasilkan perhitungan yang menunjukkan pengaruh variable independen terhadap variable dependen.

\section{Metode Analisis Data}

Menurut Priyanto (2014, p143) Pengujian hipotesis ini dilakukan dengan menggunakan metode analisis regresi linier bergandan yang bertujuan untuk menguji hubungan pengaruh antara satu variabel terhadap variabel lain. Variabel yang dipengaruhi disebut variavel dependen, sedangkan variabel yang mempengaruhi disebut variabel independen. Model persamaannya adalah sebagai berikut :

$$
\begin{aligned}
& \mathrm{Y}=\alpha+\beta 1 \mathrm{CSR}+\beta 2 \mathrm{TA}+\mathrm{e} Z=\alpha+ \\
& \beta 1 \mathrm{CSR}+\beta 2 \mathrm{TA}+\mathrm{e} \\
& T O B Q=\alpha_{0}+\beta_{1} \mathrm{CSRj}+\beta_{2} \mathrm{CETR}+\beta_{3} \mathrm{KA} \\
& +\beta_{4} \mathrm{SIZE}+\beta_{5} \mathrm{NK} \quad \beta_{6} \mathrm{CSRj}{ }^{*} \mathrm{KA}+ \\
& \beta_{7} \mathrm{CETR}^{*} \mathrm{KA}+\varepsilon
\end{aligned}
$$

Dimana:

$$
\begin{array}{ll}
\text { TOBQ } & \begin{array}{c}
\text { Nilai Perusahaan yang diwakili } \\
\text { oleh variabel Tobin's Q }
\end{array} \\
\text { CSRj : } & \text { Corporate Social Responsibility } \\
\text { CETR } & \text { Penghindaran pajak (tax avoidance) } \\
\text { KA } \quad: \text { Kepemilikan Asing } \\
\alpha_{0} \quad: \text { Konstanta } \\
\beta 1-\beta 7: \text { Koefisien } \\
\varepsilon \quad: \text { Error }
\end{array}
$$

\section{Hasil Dan Pembahasan}

Hasil pengujian outlier bertujuan untuk menghilangkan data-data yang ekstrim yang secara keseluruhan akan menghasilkan nilai rata-rata yang bias. Karena analisis regresi menggunakan pendekatan rata-rata maka pengujian outlier dilakukan untuk menghilangkan nilai-nilai data yang ekstrim sehingga akan dihasilkan koefisien regresi yang terbaik. Masalah outlier dideteksi karena menghasilkan nilai standardized residual sampel yang digunakan lebih besar dari absolute nilai 2. Penanggulangan outlier dilakukan dengan cara menghapus sampel yang terdeteksi adanya outlier yaitu yang menghasilkan nilai standardized residual lebih besar dari absolute nilai 2. Pengujian outlier dilakukan perubahan pada model sehingga total sampel yang pada awalnya sebesar 108 sampel berkurang menjadi 80 sampel atau terdapat 28 sampel yang dihilangkan.

Berdasarkan Tabel 1 (lampiran 1), dapat dilihat nilai minimum, maximum, mean dan standard deviation dari variabel-variabel independen yaitu variabel corporate social responsibility $\left(\mathrm{X}_{1}\right)$, variabel $\left(\mathrm{X}_{2}\right)$, dan sebagai variabel moderating yaitu variabel kepemilikan asing $\left(Z_{1}\right)$ serta variabel nilai perusahaan (Y) sebagai variabel dependen. Tabel 1 (lampiran 1) dipakai untuk membantu identifikasi terhadap besar kecilnya penyimpangan dari masing-masing variabel yang mempengruhi variabel satu dengan lainnya. Analisis statistik deskriptif dari penelitian ini menunjukkan hasil sebagai berikut ini:

a. Nilai Perusahaan (Tobin's Q)

Pada variabel Nilai Perusahaan memiliki nilai minimum sebesar 0,18152 dan nilai maximum sebesar 1,0071 dengan nilai ratarata sebesar 0,5505 serta nilai standar deviasi sebesar 0,1530. Nilai minimum sebesar 0,18152 terdapat pada perusahaan PT Tunas Alfin Tbk., yang menunjukkan bahwa perusahaan tersebut memiliki nilai perusahaan paling rendah dibandingkan dengan perusahaan lainnya. Nilai maximum sebesar 1,0071 terdapat pada perusahaan PT Berlina Tbk., yang menunjukkan bahwa perusahaan 


tersebut memiliki nilai

perusahaan paling tinggi dibandingkan dengan perusahaan lainnya.

b. Corporate Social Responsibility Pada variabel corporate social responsibility memiliki nilai minimum sebesar 0,01481 dan nilai maximum sebesar 0,05185 dengan nilai rata-rata sebesar 0,02796 serta nilai standar deviasi sebesar 0,0051. Nilai minimum sebesar 0,01481 terdapat pada perusahaan PT Suparmas Tbk., yang menunjukkan bahwa perusahaanperusahaan tersebut memiliki nilai corporate social responsibility paling rendah dibandingkan dengan perusahaan lainnya. Nilai maximum sebesar 0,05185 pada perusahaan PT Japfa Comfeed Indonesia Tbk. yang menunjukkan bahwa perusahaan tersebut memiliki nilai corporate social responsibility paling tinggi dibandingkan dengan perusahaan lainnya.

c. Tax Avoidance

Pada variabel Tax Avoidance memiliki nilai minimum sebesar $-0,57848$ dan nilai maximum sebesar $-0,01017$ dengan nilai rata-rata sebesar $-0,24862$ serta nilai standar deviasi sebesar 0,08171 . Nilai minimum sebesar $-0,57848$ terdapat pada perusahaan PT. Gajah Tunggal Tbk., yang menunjukkan bahwa perusahaan tersebut memiliki nilai Tax Avoidance paling rendah dibandingkan dengan perusahaan lainnya. Nilai maximum sebesar $-0,01017$ terdapat pada perusahaan PT Malindo Feedmill Tbk., yang menunjukkan bahwa perusahaan tersebut memiliki nilai Tax Avoidance paling tinggi dibandingkan dengan perusahaan lainnya.

d. Kepemilikan Asing

Pada variabel kepemilikan asing memiliki nilai minimum sebesar 0,00032 dan nilai maximum sebesar 1,0000 dengan nilai ratarata sebesar 0,4690 serta nilai standar deviasi sebesar 0,2909. Nilai minimum sebesar 0,0032 terdapat pada perusahaan PT Lionmesh Prima Tbk. yang menunjukkan bahwa perusahaan tersebut memiliki nilai kepemilikan asing paling rendah dibandingkan dengan perusahaan lainnya. Nilai maximum sebesar 1,0000 pada perusahaan PT Pelat Timah NusantaraTbk., yang menunjukkan bahwa perusahaan tersebut memiliki nilai kepemilkan asing paling tinggi dibandingkan dengan perusahaan lainnya.

Dari Tabel 4 (lampiran 5), dapat dilihat bahwa koefisien $(\mathrm{R})$ yaitu sebesar 0,440 , nilai tersebut menunjukkan bahwa korelasi atau hubungan antara Corporate Social Responsibility (X1), Tax Avoidance (X2), Corporate Social Responsibility (X1) dan Kepemilikan Asing (Z1), Tax Avoidance (X2) dan Kepemilikan Asing (Z1), dan Kepemilikan Asing (Z1) dengan Nilai Perusahaan (Y) dinyatakan memiliki hubungan yang kuat dikarenakan memiliki nilai korelasi $>0,50$.

Sedangkan nilai Adjusted $R$ Square (koefisien determinasi) dihasilkan angka sebesar 0,139 yang berarti bahwa variasi variabel $\mathrm{Q}$ dapat dijelaskan oleh variabel Corporate Social Responsibility (X1), Tax Avoidance (X2), Corporate Social Responsibility (X1) dan Kepemilikan Asing (Z1), Tax Avoidance (X2) dan Kepemilikan Asing (Z1), dan Kepemilikan Asing (Z1) adalah sebesar 0,139 atau sebesar $13,9 \%$ sedangkan sisanya sebesar $86,1 \%$ dijelaskan oleh faktor-faktor lain yang tidak terdapat dalam penelitian ini. 
Tabel 4 (lampiran 5), dapat dilihat bahwa koefisien $(\mathrm{R})$ yaitu sebesar 0,440 , nilai tersebut menunjukkan bahwa korelasi atau hubungan antara Corporate Social Responsibility (X1), Tax Avoidance (X2), Corporate Social Responsibility (X1) dan Kepemilikan Asing (Z1), Tax Avoidance (X2) dan Kepemilikan Asing (Z1), dan Kepemilikan Asing (Z1) dengan Nilai Perusahaan (Y) dinyatakan memiliki hubungan yang kuat dikarenakan memiliki nilai korelasi > 0,50.

Sedangkan nilai Adjusted $R$ Square (koefisien determinasi) dihasilkan angka sebesar 0,139 yang berarti bahwa variasi variabel $\mathrm{Q}$ dapat dijelaskan oleh variabel Corporate Social Responsibility (X1), Tax Avoidance (X2), Corporate Social Responsibility (X1) dan Kepemilikan Asing (Z1), Tax Avoidance (X2) dan Kepemilikan Asing (Z1), dan Kepemilikan Asing (Z1) adalah sebesar 0,139 atau sebesar $13,9 \%$ sedangkan sisanya sebesar $86,1 \%$ dijelaskan oleh faktor-faktor lain yang tidak terdapat dalam penelitian ini.

Dari hasil tabel uji $\mathrm{F}$ Tabel 5 (lampiran 6) dapat dilihat bahwa $F_{\text {hitung }}$ adalah sebesar 3,551 ( $\mathrm{F}_{\text {tabel }}$ sebesar : 2,329) dengan nilai signifikan sebesar 0,006 . Oleh karena $F_{\text {hitung }}$ lebih besar dari $\mathrm{F}_{\text {tabel }}$ dan probabilitas jauh lebih kecil dari 0,05 yang berarti $\mathrm{Ha}$ diterima, oleh karena nilai signifikan lebih kecil dari $5 \%$ yaitu $0,006<0,05$, maka dapat ditarik kesimpulan bahwa koefisien regresi corporate social responsibility (X1), tax avoidance (X2), corporate social responsibility (X1) dengan Kepemilikan Asing (Z1), tax avoidance (X2) dengan Kepemilikan Asing (Z1), secara simultan atau bersama-sama berpengaruh signifikan terhadap nilai perusahaan $(\mathrm{Y})$. Dengan demikian model regresi dapat digunakan untuk memprediksi nilai perusahaan $(\mathrm{Y})$.

\section{Corporate social responsibility berpengaruh negatif terhadap nilai perusahaan.}

Dari hasil pengujian regresi Tabel 6 (lampiran 7) pada hipotesis pertama dengan menggunakan program SPSS menunjukkan nilai koefisien 0,174 dengan signifikansi sebesar 0,592 > 0,050 . Dengan demikian hipotesis $\mathrm{H}_{1}$ dari penelitian ini ditolak, kesimpulannya adalah tidak terdapat pengaruh corporate social responsibility terhadap nilai perusahaan manufaktur di Bursa Efek Indonesia periode 2016-2018.

\section{Tax Avoidance berpengaruh positif terhadap nilai perusahaan.}

Dari hasil pengujian regresi pada hipotesis kedua dengan menggunakan program SPSS menunjukkan nilai koefisien $-0,174$ dengan signifikansi $0,001<0,050$. Dengan demikian hipotesis $\mathrm{H}_{2}$ dari penelitian ini diterima, kesimpulannya adalah terdapat pengaruh dari tax avoidance terhadap nilai perusahaan manufaktur di Bursa Efek Indonesia periode 2016-2018.

Kepemilikan asing memperlemah hubungan antara corporate social responsibility dan nilai perusahaan.

Dari hasil pengujian regresi pada hipotesis ketiga dengan menggunakan program SPSS menunjukkan nilai koefisien -0,522 dengan signifikansi $0,590>0,050$. Dengan demikian hipotesis $\mathrm{H}_{3}$ dari penelitian ini ditolak, yang artinya tidak terdapat pengaruh untuk hubungan antara kepemilikan asing dan corporate social responsibility terhadap nilai perusahaan. Kesimpulannya adalah kepemilikan asing tidak mampu menjadi variabel moderating yang memperkuat antara corporate social responsibility terhadap nilai perusahaan manufaktur di Bursa Efek Indonesia periode 2016-2018.

Kepemilikan asing memperkuat hubungan antara tax avoidance dan nilai perusahaan. 
Dari hasil pengujian regresi pada hipotesis keempat dengan menggunakan program SPSS 25 menunjukkan nilai koefisien 1,520 dengan signifikansi 0,006 $<0,050$. Dengan demikian hipotesis $\mathrm{H}_{4}$ dari penelitian ini diterima, yang artinya terdapat pengaruh untuk hubungan antara kepemilikan asing dan tax avoidance terhadap nilai perusahaan. Kesimpulannya adalah kepemilikan asing mampu menjadi variabel moderating yang memperkuat hubungan antara tax avoidance terhadap nilai perusahaan manufaktur di Bursa Efek Indonesia periode 2016-2018.

\section{Simpulan}

Berdasarkan hasil penelitian dapat di simpulkan bahwa Corporate social responsibility berpengaruh terhadap nilai perusahaan, dan Kepemilikan asing tidak mampu menjadi variabel moderating yang memperkuat hubungan antara corporate social responsibility dengan nilai perusahaan hasil ini tidak sejalan dengan tujuan penelitian.

Sedangkan Tax avoidance berpengaruh terhadap nilai perusahaan dan Kepemilikan asing mampu menjadi variabel moderating yang memperkuat hubungan antara tax avoidance dengan nilai perusahaan hasil ini sejalan dengan tujuan penelitian, dan penemuan terbaru dalam penelitian ini adalah adanya penambahan variabel moderating kepemilikan asing yang berpengaruh terhadap nilai perusahaan hal ini menjadi pengembangan penelitian atas penelitian terdahulu yaitu penelitian yang di lakukan oleh simamatra (2014) serta jonathan dan vivi (2016).

\section{Daftar Pustaka}

Choi, Hyang Mi, Wonsik Sul, Sang Kee Min. 2012. Foreign board membership and firm value in Korea. Management Decision, Vol. 50 Iss 2 pp. 207 - 233
Ebert, Ronald J dan Ricky W. Griffin 2003, Bisnis, edisi 6, Jakarta:Prenhallindo

Galatang, Jessica, Sri Murni, Dedy Baramuli. 2016. Analisis of The Capital Structure, The Size of the Company, Return on Equity and Risks Company Against The Company (Case Study on Cigarette Listed on BEI 2011-2014). Jurnal Berkala Ilmiah Efisiensi. Volume 16 No.03 Tahun 2016.

Jensen dan Meckling. 1976. Theory of The Firm: Managerial Behaviour, Agency Cost, and Ownership Structure. Journal Of Financial Economics, Vol. 13, pp. 305-360.

Jonathan \& Vivi Adeyani Tandean. 2016. Pengaruh Tax Avoidance terhadap Nilai Perusahaan dengan Profitabilitas sebagai Variabel Pemoderasi. Prosiding Seminar Nasional Multi Disiplin Ilmu \& Call for Papers Unisbank. Jakarta.

Languju, Octavia, Marjam Mangantar, Hizkia H.D. Tasik. 2016. Pengaruh Return on Equity, Ukuran Perusahaan, Price Earning Ratio dan Struktur Modal Terhadap Nilai Perusahaan Property and Real Estate Terdaftar di Bursa Efek Indonesia. Jurnal Berkala Ilmiah Efisiensi. Volume 16 No.02 Tahun 2016. Jurnal EMBA. Vol.4 No.2 Juni 2016, Hal 485-497.

Manoppo, Heven dan Fitty Valdi Arie. 2016. The Influence of Capital Structure, Company Size and Profitability towards Automotive company Value of IDX Period 2011-2014

Muttakin, M. B., Khan, A., \& Subramaniam, N. (2015). Firm characteristics, board diversity and corporate social responsibility: Evidence from Bangladesh. Pacific 
Accounting Review, 27(3), 353-372.

Putri, Ayu Kemala, Made Sudarma, Bambang Purnomosidhi. 2015. Pengaruh Corporate Social Responsibility terhadap Nilai Perusahaan dengan Ukuran Perusahaan dan Jumlah Dewan Komisaris sebagai Variabel Pemoderasi (Studi pada Perusahaan Manufaktur yang terdaftar Bursa Efek Indonesia). Jurnal Aplikasi Manajemen (JAM) Vol 14 No 2, 2016

Priyatno, D. (2014). SPSS 22 Pengolah Data Terpraktis. Yogyakarta: Andi Yogyakarta

Pohan, C. A. (2014). Manajemen Perpajakan: Strategi Perencanaan Pajak dan Bisnis Jakarta: Gramedia

Retno, Reny Dyah dan Denies Priantinah. 2012. Pengaruh Good Corporate Governance dan Pengungkapan Corporate Social Responsibility Terhadap Nilai Perusahaan (Studi Empiris Pada Perusahaan yang Terdaftar di Bursa Efek Indonesia Periode 2007-2010). Jurnal Nominal Volume I Nomor I Tahun 2012.

Septiawan, I Kadek Hery dan Ni Gst Putu Wirawati. 2016. Pengaruh Kepemilikan Asing, Ukuran Perusahan, dan Kebijakan Utang Pada Kos Keagenan. EJurnal Akuntansi Universitas
Udayana. Vol.17.1. Oktober (2016): 481-508. ISSN: 23028556 .

Sujarweni, V. W. (2014). Metodologi Penelitian. Yogyakarta: Pustaka Baru Press

Simarmata, A.P.P., 2014. Pengaruh Tax Avoidance Jangka Panjang Terhadap Nilai Perusahaan Dengan Kepemilikan Institusional Sebagai Variabel Pemoderasi.

Sholekah, F. W., dan Venusita, L., 2014, "Pengaruh Kepemilikan Manajerial, Kepemilikan Institusional, Leverage, Firm Size, dan Corporate Social Responsibility pada perusahaan High Profile yang terdaftar di Bursa Efek Indonesia periode 2008-2012 Volume 2 Nomor 3 Juli 2014.

Wijayanti. Rita. 2016. Pengaruh Pengungkapan Sustainability Report Terhadap Kinerja Keuangan Perusahaan. Syariah Paper Accounting FEB UMS. ISSN 2460-0784

Wiranata, Yulius Ardy dan Yeterina Widi Nugrahanti. 2013. Pengaruh Struktur Kepemilikan Terhadap Profitabilitas Perusahaan Manufaktur di Indonesia. Jurnal Akuntansi dan Keuangan, Vol. 15, No. 1, Mei 2013, 15-26. ISSN 1411-0288 print / ISSN 2338-8137 online. 


\section{Lampiran}

\section{Tabel 1 Analisis Deskriptif}

\begin{tabular}{l|c|r|r|r|r}
\multicolumn{7}{c}{ Descriptive Statistics } \\
& N & Minimum & Maximum & Mean & Std. Deviation \\
\hline CSR & 80 & .01481 & .05185 & .0279630 & .00513403 \\
\hline Tax Avoidance & 80 & -.57848 & -.01017 & -.2486270 & .08171027 \\
\hline Kepemilikan Asing & 80 & .00032 & 1.00000 & .4690893 & .29093475 \\
\hline Nilai Perusahaan & 80 & .18152 & 1.00710 & .5505996 & .15302338 \\
\hline Valid N (listwise) & 80 & & & & \\
\hline
\end{tabular}

\section{Gambar 1 Normal P-P Plot}

\section{Hasil Uji Normal}

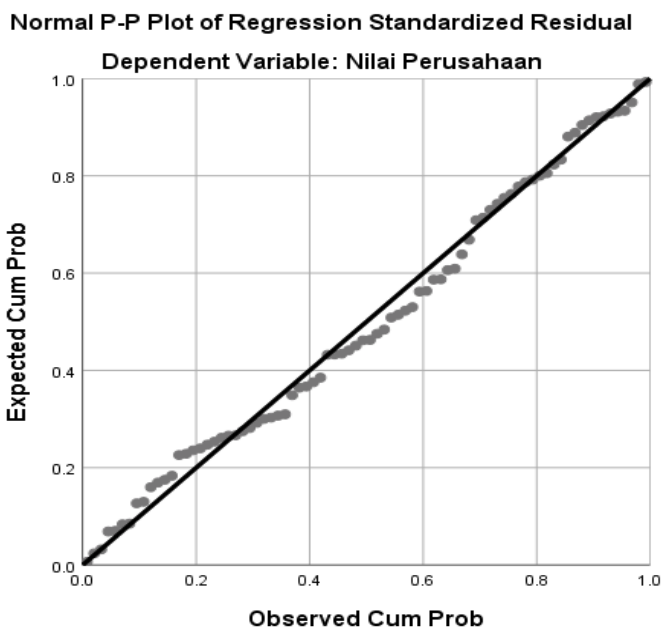

Gambar2 Scatterplot

Uji Heteroskedastisitas




Tabel 2 Uji Multikolonieritas

\section{Coefficients ${ }^{a}$}

\begin{tabular}{|c|c|c|}
\hline \multirow[b]{2}{*}{ Model } & \multicolumn{2}{|c|}{ Collinearity Statistics } \\
\hline & Tolerance & VIF \\
\hline 1 (Constant) & & \\
\hline CSR & 0.959 & 1.043 \\
\hline Tax Avoidance & 0.974 & 1.027 \\
\hline $\begin{array}{l}\text { Kepemilikan } \\
\text { Asing }\end{array}$ & 0.981 & 1.019 \\
\hline CSR_KA & 0.961 & 1.039 \\
\hline TA_KA & 0.941 & 1.059 \\
\hline
\end{tabular}

Tabel 3 Uji Autokorelasi

\begin{tabular}{|c|c|c|c|c|c|c|}
\hline \multicolumn{7}{|c|}{ Model Summary } \\
\hline Model & $\mathrm{R}$ & R Square & $\begin{array}{l}\text { Adjusted } \\
\text { R Square }\end{array}$ & Std. Error of the Estimate & $\begin{array}{l}\text { Change } \\
\text { Statistics } \\
\text { R Square } \\
\text { Change }\end{array}$ & $\begin{array}{l}\text { Durbin- } \\
\text { Watson }\end{array}$ \\
\hline 1 & $.440^{a}$ & 0.193 & 0.139 & 0.14199040 & 0.193 & 2.101 \\
\hline
\end{tabular}

Tabel 4 Hasil Uji Koefisien Determinasi

Model Summary

\begin{tabular}{lr|r|r|r} 
Model & R & R Square & \multicolumn{2}{|c}{$\begin{array}{c}\text { Adjusted R } \\
\text { Std. Error of the }\end{array}$} \\
\hline 1 & $.440^{\mathrm{a}}$ & 0.193 & 0.139 & 0.14199040 \\
\hline
\end{tabular}

a. Predictors: (Constant), TA_KA, CSR, Tax Avoidance,

b. Dependent Variable: Nilai Perusahaan

\section{Tabel 5 Hasil Uji Statistik F}

\begin{tabular}{|c|c|c|c|c|c|c|}
\hline \multicolumn{7}{|c|}{ ANOVA $^{a}$} \\
\hline Model & & $\begin{array}{c}\text { Sum of } \\
\text { Squares }\end{array}$ & df & $\begin{array}{l}\text { Mean } \\
\text { Square }\end{array}$ & $\mathrm{F}$ & Sig. \\
\hline \multirow[t]{3}{*}{1} & $\begin{array}{l}\text { Regressio } \\
n\end{array}$ & 0.358 & 5 & 0.072 & 3.551 & $.006^{\mathrm{b}}$ \\
\hline & Residual & 1.492 & 74 & 0.020 & & \\
\hline & Total & 1.850 & 79 & & & \\
\hline
\end{tabular}

a. Dependent Variable: Nilai Perusahaan

b. Predictors: (Constant), TA_KA, CSR, Tax Avoidance, CSR_KA, Kepemilikan 


\section{Tabel 6 Hasil Regresi Linier Berganda}

\begin{tabular}{|c|c|c|c|c|c|c|}
\hline & & & efficient & & & \\
\hline & & $\begin{array}{l}\text { Unstand } \\
\text { Coeffi }\end{array}$ & $\begin{array}{l}\text { lardized } \\
\text { cients }\end{array}$ & $\begin{array}{c}\text { Standardiz } \\
\text { ed } \\
\text { Coefficient } \\
\text { s }\end{array}$ & & \\
\hline Model & & $\mathrm{B}$ & Std. Error & Beta & $\mathrm{t}$ & Sig. \\
\hline 1 & (Constant) & -0.019 & 0.303 & & -0.064 & 0.949 \\
\hline & CSR & 5.196 & 9.644 & 0.174 & 0.539 & 0.592 \\
\hline & $\begin{array}{l}\text { Tax } \\
\text { Avoidance }\end{array}$ & -1.427 & 0.501 & -0.762 & -2.849 & 0.006 \\
\hline & $\begin{array}{l}\text { Kepemilik } \\
\text { an Asing }\end{array}$ & 1.091 & 0.540 & 2.074 & 2.018 & 0.047 \\
\hline & CSR_KA & -9.395 & 17.336 & -0.522 & -0.542 & 0.590 \\
\hline & TA_KA & 2.778 & 0.851 & 1.520 & 3.263 & 0.002 \\
\hline
\end{tabular}


Jurnal Akuntansi Bisnis 